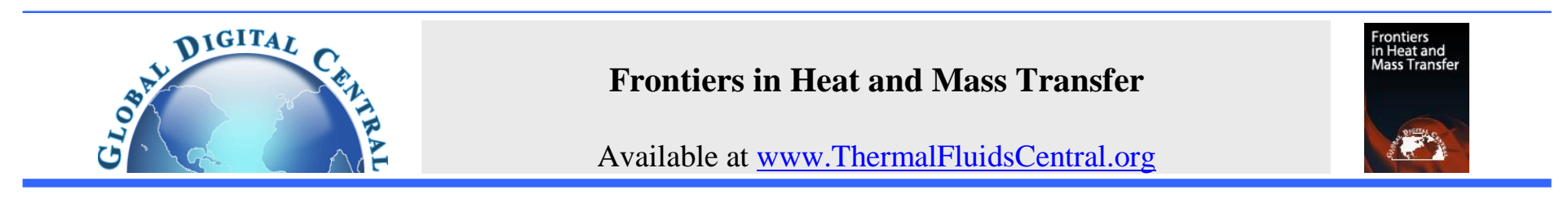

\title{
A COMPREHENSIVE REVIEW OF PERFORMANCE ANALYSIS OF WITH AND WITHOUT FINS SOLAR THERMAL COLLECTOR
}

\author{
Sushil Kumar ${ }^{\mathrm{a}}$, Robin Thakur ${ }^{\mathrm{a}}$, Amar Raj Singh Suria ${ }^{\mathrm{a}}$ Kamal Kashyap ${ }^{\mathrm{a}}$, Arvind Singhy ${ }^{\mathrm{a}}$, Sunil Kumar ${ }^{\mathrm{a}}$, Anil Kumar ${ }^{\mathrm{b}}$ \\ ${ }^{a}$ Faculty of Engineering and Technology, Shoolini University, 173212, Solan, Himachal Pradesh, India \\ ${ }^{b}$ Department of Mechanical Engineering, University of Petroleum and Energy Studies, 248001, Dehradun, Uttarakhand, India
}

\begin{abstract}
Solar thermal collector is a simple, economic, and environment friendly equipment which is used to utilize solar energy for various agriculture and industrial applications. The investigators mainly focus on the improvement of the thermal performance by providing various fins shapes underside of the absorber plate in the single pass and double pass solar thermal collector. This work discusses the influence of different shaped fins used by various researchers in improving the thermal performance of thermal collectors. Fin's design, geometries used, and their influence on turbulence and thermal performance have also been discussed. As per the literature review and comparative study the heat transfer rate is greater for solar air thermal collector with fins as compared to solar air thermal collector without fins.
\end{abstract}

Keywords: Fins, solar energy, heat exchanger, thermohydraulic performance.

\section{INTRODUCTION}

Flat plate solar collectors are very popular among various nonconcentrated solar thermal collectors because of their simple design and wide range of applications. Flat plate air heating solar collectors are widely used for space heating in households and for drying purposes in industry, agricultural fields, and laundry Aboghrara et al. (2017). There are mainly two methods to improve heat transfer which are active and passive methods (Thapa et al. 2021). Several improvements in design have been proposed by various researchers to increase the heat transfer in flat plate solar collectors. One of the several design methodologies includes increase in heat transfer area of the collectors using longitudinal finned absorber, reflecting finned absorber, rectangular finned absorber etc. (Kashyap et al. 2019), (Kumar et al. 2020). Experimentally studied the effect of jet impingement on the corrugated absorber plate and juxtaposed it with conventional solar air heater on flat plat absorber and concluded that the flow jet impingement on corrugated plat absorber remains a strong function of heat transfer augmentation (Kashyap et al. 2019), (Kumar et al. 2020).

Ansari and Bazargan (2018) experimentally studied the thermal performance of a flat plate solar air heater having repeated ribs. The optimum set of parameters in an air heating application were found using genetic algorithm and it was concluded that at low air mass flow conditions the thermal efficiency improved by more than $9 \%$ by employing ribs in the flat plate solar air heater. Cuzminschi et al. (2018) experimentally tested and numerically simulated (using an open source numerical CFD software) an innovative design of solar air heater for 50 weeks and comparable results between numerical simulation an experimentation were obtained by using an open source numerical CFD software. This device will have used for the maintenance of constant comfortable temperature condition inside buildings, greenhouses, passive heating of buildings.

Heydari and Mesgarpour (2018) experimentally and numerically investigated a triangular cross-section channel solar air heater which causes helical flow of air through it. The results show that newly designed solar sir heater is $14.7 \%$ thermally more efficient than higher than simple duct and $8.6 \%$ than double pass-finned solar air heater. Priyam and Chand (2018) theoretically studied and concluded that for a complete mass flow rate and a constant amp value of the $0.75 \mathrm{~cm}$ the thermohydraulic efficiency of a wavy fin single pass solar air heater decreases with increases in Wavelength. Singh and Singh (2018a) experimentally and numerically investigated a new designed curved solar air heater. The results showed that the curved solar air heater has more thermal efficiency than the flat plate solar air heater.

Singh Bisht et al. (2018) reviewed different artificially roughened solar air heaters. A different roughness, parameters like relative roughness pitch, relative roughness, and height shape of ribs, angle of attack, and their effects on heat transfer and pressure drop and thermal hydraulic performance was discussed in detail. Singh and Singh (2018b) expansively studied several geometries for rib roughness for conventional solar air heater. Significant amount of heat transfer augmentation was attained using various rib designs along with some pressure drop.

Jia B. et al. (2019) the function of the spiral shape spoiler solar air heaters (SSAH) was studied and found out that the temperature difference has a liner relation to irradiation between inlet and outlet. This type of solar air heaters has a higher heat collection efficiency as compared with the conventional and serpentine SAH. Wadhawan et al. (2018) studied the effect of thermal energy storage device on the rectangular duct rise. The working of solar air heater coupled with thermal energy storage device was analysed with the help of CFD analysis. Turbulence model k- $\epsilon$ RNG model were used and were in decent agreement with the experimental outcomes.

Jin D. et al. (2019) numerically studied the heat transfer and fluid flow characteristics of a multiple V-shaped rib roughened solar air heater (SAH). It was concluded that The Multiple V-shaped ribs significantly augmented the heat transfer and 2.35 was the max thermos hydraulic found. Kumar and Premachandran (2019) numerically studied the effect on heat transfer rate caused by atmospheric wind in natural convection-based 3D inclined rectangular channel solar air heaters 
(SAH). It is concluded that external wind imparts great impact on the flow pattern and heat transfer in the SAH Channel.

Mzad et al. (2019) found out that the assessment pertaining to the thermal efficacy of solar air collectors with regards to the correct design as well as dimensions of the collector for a provided application. The acquired outcomes highlight optimum collector orientations as well as tilts for amount of time of the season. The rise of the inclination angle gives higher differences in energy because of the boost of the zenithal angle. Lastly it is wrapped up that selecting the appropriate materials of absorber, glass cover and insulation boost heat transfers in the air-vein as well as lower considerably substantially leading and bottom losses.

\section{HEAT TRANSFER CHARACTERISTICS FINS AND WITHOUT FINS SOLAR THERMAL COLLECTOR}

Ahmad Fudholi (2013a) conducted the performance as well as cost benefit evaluation of double-pass solar collector with as well as without fins. Outcomes suggested that the thermal efficiency is proportional to the solar intensity at a specific mass flow rate and that by enhancing the Nusselt number concurrently would drop the outlet temperature level at any kind of solar intensity. Ahmad Fudholi (2013b) developed Steady state energy balance equations for the finned double-pass solar collector. These equations were solved by making use of the matrix inversion method technique. The forecasted outcomes remained in agreement with the outcomes acquired from the experiments.

Ali Daliran, (2018) found that using fins in air channel not just decreases $\mathrm{Nu}$ from 19.67 to 16.23 , yet also because of decreasing hydraulic diameter as well as developing air flow turbulence, creates rise of heat transfer coefficient from absorber plate to air flow as well as subsequently decrease of the overall heat loss and greater outlet air temperature levels. Evangelos Bellos (2018) studied the optimal number as well as location of the inner fins in the absorber of a parabolic trough collector and proved that the absorber with 3 fins in the lower part is the optimal instance with $0.51 \%$ thermal efficiency improvement. Ramanan (2016) studied methodically temperature profile in the two collectors, variation of thermo-siphon system as well as change in efficiency of the solar water heaters relative to time and observed that giving inner fins resulted in a rise in efficiency of about $4.5 \%$ as contrasted to standard plain tubes.

Bhattacharyya et al. (2017) researched the performance of an extruded finned plate air heating solar collector for the applications in paddy drying out. The analysis revealed that finned plate air heating solar battery with 80 fins, 0.6 Height to Duct length ratio as well as 2 $\mathrm{mm}$ thickness of fin, yield most ideal results at Guwahati weather. Evangelos Bellos (2017) examined exegetically that amongst the various fin sizes in the parabolic trough collectors operating with gas working fluids, the fin of $10 \mathrm{~mm}$ proved to be the most appropriate. And that helium as a working fluid was better efficient up to $290^{\circ} \mathrm{C}$, whereas $\mathrm{CO}_{2}$ at higher temperature. Farkas (2018) experimentally evaluated the thermal performance of horizontal and vertical finned double-pass solar air collectors integrated with drying chamber which included 2 main parts as solar collector and dryer and concluded that by changing the direction from vertical to horizontal the everyday efficiency increased by $10 \%$. After $5 \mathrm{~h}$ drying of $2 \mathrm{~kg}$ apple slices, the final weights were 1.16 and $1.37 \mathrm{~kg}$ by using vertical-finned and horizontal collectors, respectively.

Rafael Gustavo Schreibera (2018) analyzed two-point incremental forming process parameters, having partial die for the manufacturing of solar collector absorber fin utilizing a $1 \mathrm{~mm}$ thick aluminium AA1200H14 and determined that incremental sheet forming offers more formability in comparison to conventional forming. Murugan et al. (2019) experimentally investigated the effects of Corrugated Booster Reflectors in the plain tube solar thermal collector,
Corrugated Booster Reflectors with Typical Twist, and Centrally Finned Twist of twist ratios $3 \& 6$ and found out that The plain tube solar collector with corrugated booster reflectors (plain tube CBR SC) provided higher heat transfer rate nearly $8.25 \%$ over the plain tube solar collector with flat booster reflectors (plain tube FBR SC) for the same collector size. The CBR with the CFT offered a significant heat transfer enhancement as well as the thermal performance compared to the CBR with the TT at similar twist ratio. The main reason for this was the centrally attached nail creates additional vortex and disturbances to the fluids near the tube wall.

\section{HEAT TRANSFER CHARACTERISTICS WITH AND WITHOUT SOLAR THERMAL COLLECTOR}

Indrajit (1985) experimented with solar air heaters with simple designed non-porous absorber which revealed that including fins is advantageous just at less circulation rates. A theoretical model, created on the presumption that the absorber plate is at a constant temperature, proved to be valid only at a small flow rate of air less than equal to 0.00813 $\mathrm{kg} / \mathrm{sec}$, per unit area of the collector. H.P. Garg and Ranjana Jha (1991) carried out a numerical simulation of a theoretically developed design to evaluate the effect of the number of rectangle-shaped fins, the length of the depth of the air channel, the airflow rate, etc. on the thermal performance. The outlet air temperature, as well as thus the overall heat energy collected, are found to increase with a boost in the number of fins as well as with a decrease in the duct depth while maintaining all other functional parameters constant.

Naphon (2005) studied numerically the performance as well as entropy generation of the double pass flat plate solar air heater along with longitudinal fins. The predictions were carried out at air mass flow rate ranging in between 0.02 and $0.1 \mathrm{~kg} / \mathrm{s}$. It was found that the thermal efficiency increases with increasing the elevation as well as variety of fins. Yeh and Ho (2009) theoretically examined, the influence of external recycle on the collector efficiency in solar air heaters with inner fins attached. It was found that considerable enhancement in collector efficiency is obtainable if the operation is carried out with an external recycle, where the preferable effect conquers the unwanted effect. The improvement increases with increasing reflux ratio, especially for operating at lower air flow rate with higher inlet air temperature level.

Nwosu (2010) theoretically found that pin fins are reasonably effective heat transfer augmentation features with good aerodynamic performance and therefore find application in some solar air heaters. The exergy optimization method was employed in sizing the pin fin. Outcomes suggested that the high efficiency of the optimized fin enhances the heat absorption as well as the dissipation potential of a solar air heating system. Omojaro and Aldabbagh (2010) experimentally analyzed the thermal performance of a double-pass and single solar air heater with fins attached and making use of a steel wire mesh as an absorber plate. The result show that if a single or double solar air heater using steel wire mesh arrange in layers as an absorber plate and packing material when compared with a conventional solar air heater shows a much more considerable enhancement in the thermal efficiency.

El-khawajah et al. (2011) experimentally investigated the thermal performance of a double pass solar air heating system with 2,4 , and 6 fins attached to it. The effects of mass flow rate of air on the outlet temperature and thermal efficiency were also found. The indicated results reveal that the efficiency increases with enhancing the mass flow rate and the maximum efficiency was obtained by using 6 fins at the same mass flow rate. El-Sebaii et al. (2011) examined theoretically as well as experimentally the double pass-finned plate solar air heating system. The effect of mass flow rates of air on pressure drop, thermal and thermohydraulic efficiencies of the double pass-finned as well as vcorrugated plate solar air heaters were additionally examined. The results showed that the double pass v-corrugated plate solar air heater is 9.3-11.9\% more efficient compared to the double pass-finned plate solar air heater. The optimum values of the thermohydraulic efficiencies 
for the double pass-finned and v-corrugated plate solar air heaters are also obtained when the mass flow rates of the flowing air equal 0.0125 and $0.0225 \mathrm{~kg} / \mathrm{s}$, respectively.

Mohamed S.Yousef et al. (2019) experimentally examined heat transfer characteristics of PCM storage unit, appropriate to solar still system, making use of hollow cylindrical pin fins installed in PCM which serve as thermal conductivity enhancer (TCE). The outcomes revealed that the existence of PCM adversely influences the daytime freshwater productivity with a significant increment in the general freshwater return of the still. Fakoor Pakdaman et al. (2011) experimentally evaluated the different thermal characteristics of a natural-convection flat-plate solar air-heater with longitudinal rectangular fins array. Solar radiation and ambient temperature were also considered as independent parameters and other characteristics of the system were empirically modelled based on these variables. The result show that thermal efficiency of the system increases with the rise in solar radiation and ambient temperature and heat transfer of solar airheaters enhanced with the application of longitudinal rectangular fins array and it also shows negligible dependency on the inclination angle of the device.

Ho and Chen (2008) investigated theoretically the collector efficiency of upward-type double-pass flat plate solar air heaters with fins connected as well as exterior recycle. The double-pass device presented in this article was designed for creating a solar collector with heat transfer area double as well as the extended area of fins between the absorbing plate and heated air. It is concluded from this study that recycle effect can increase the efficiency of collector on the recyclic device, specifically for the case in which distance between tubes and number of fins attached is smaller. C.D. Ho (2009) investigated by means of both theoretical as well as experimental techniques the performance of a solar air heating system featured with double pass along with baffles as well as fins design for the impact of reusing operation. Based upon both theoretical plus experimental results, the collector efficiency of the fined plus baffled double pass with recycle design is a lot more than the other designs under different reflux ratios and mass flow rates.

Kumar and Rosen (2011) examined a photovoltaic/thermal (PV/T) solar air heating system with a double pass configuration and vertical fins in the lower channel which are organized perpendicular to the direction of air flow to improve the heat transfer rate and efficiency. It was wrapped up that the mass flow rate of air significantly affects the heat transfer on solar air heating systems. And the thermal efficiency of the proposed design duct is observed nearly $14 \%$ more as compared to the smooth duct and the thermal efficiency is boosted with increasing the value of mass flow rate. Yeh (2012) investigated theoretically the impact of internal recycle on the collector efficiency in upward-type flat-plate solar air heaters connected with fins. The improvement in collector efficiency increases with increasing reflux ratio, especially for running at lower air flow rate with greater inlet air temperature. It is found that more than $100 \%$ of enhancement in collector efficiency is acquired by recycling operation.

Kasperski and Nemś (2013) studied the thermo-hydraulic analysis of a solar air heating system with an internal multiple-fin array. Proposed multiple fin-array technology makes it possible for to reduce the required air flux of $7-10$ times in contrast to the smooth pipe arrangement of the absorber. Even with the flux reduced, the efficiency of internal multiple-fin array arrangement is higher than the one offered for smooth pipe arrangement. The solution could be used in solar space heating with rock bed storage systems or in solar dryers. Yang et al. (2014) optimized the design of a solar air heater with offset strip fins by numerical modelling basically to increase the thermal efficiency of solar air heaters. A heating system with the offset rectangle-shaped fins on the absorber plate was first enhanced numerically which shows that the optimal style maximizes the convection heat transfer in the airflow pass and reduces the heat loss of the heating system.

Mahmood et al. (2015) build and evaluated single-pass and double-pass solar air heaters (SAHs) with four transverse fins. These fins were painted dark black and put transversely to create four equalspaced areas. In this work, the thermal efficiency and outlet temperature were studied in a geographical location situated in the city of Famagusta, North Cyprus. The results demonstrate a significant enhancement in the thermal efficiency and outlet air temperature. Nemś and Kasperski (2016) proposed a unique high-temperature solar air heater to transform solar energy to heat for space heating in weather conditions of Poland. The aim of the research study was to validate the formerly created mathematical model of heat transfer procedures. The comparison shows a relatively small deviation between the results of model calculation and the experimental results. Priyam and Chand (2016) analytically examined the performance analysis of finned absorber solar air heating system. The use of wavy fins enhanced the heat transfer surface area as well as the heat transfer coefficient to improve the thermal performance of solar air heater. It has also been found that the thermal efficiency enhanced with wavy finned absorber solar air heater and effective temperature rise in comparison to corresponding flat plate collector operating under similar conditions.

Bhattacharyya et al. (2017) studied theoretically the air heating solar collector with rectangle-shaped fins for different controlling parameters such as numbers of fins, H/D ratios and fin thicknesses to use it for paddy drying. The optimum design of a solar air heating system with 80 numbers of fins and $0.6 \mathrm{H} / \mathrm{D}$ ratio with $2 \mathrm{~mm}$ fin thickness produces higher outlet temperature at steady state than needed. Fan et al. (2017) developed a dynamic design for a hybrid Photovoltaic Thermal Collector-Solar Air Heating System (PVT-SAH) having longitudinal fins. The study shows that the use of a dynamic model could be important because the system could have significant Time Constants if the boundary conditions change in a dynamic manner. Hosseini et al. (2017) numerically examined the performance of solar chimney as a natural convection solar air heater with longitudinal rectangular-shaped fins. The results revealed that thermal efficiency and mass flow rate improves in a solar chimney with fins rather than a conventional flat chimney and also discontinuous fins can improve or reduce the performance of solar chimney.

Kumar and Chand (2017) dealt with the performance improvement of the solar air collector with making use of herringbone corrugated fins and revealed that herringbone corrugated fins provide increased heat transfer area and extend the circulation length of air leading to much better fluid blending so heat transfer rate increases. Kabeel et al. (2017) examined experimentally, the thermal performance of the finned plate solar air heating system (FPSAH) with using paraffin wax as PCM. The experimental results revealed that the immediate and daily efficiencies of the FPSAH with and without utilizing the PCM increases when the mass flow rate increases. Rai et al. (2017) examined the impact of variation of system and operating parameters such as fin spacing, fin height, air mass flow rate and insolation on the thermal and thermohydraulic (effective) efficiencies. Outcomes suggested that the thermal efficiency increases continuously with boost in mass flow rate, whereas thermohydraulic efficiency increases approximately a beginning value of air mass flow rate which obtains a maximum and after that decreases sharply for a provided fin spacing and fin height.

Bai et al. (2018) established and experimentally studied a unique solar thermal storage heating equipment that is integrated with several extremely efficient solar collecting heat storage units (HSU) that filled with a phase-change material (PCM) and integrated with finned heat pipe to boost the heat dissipation process It was found from the study that the prototype equipment could meet larger heat capacity storage with reasonable heat loss in the daytime and highly efficient heat dissipation rate in the night-time. Fan et al. (2018) a strategy for the optimal design of PVT-SAH system was proposed to maximize the useful thermal energy and net electricity gains of a hybrid PVT-SAH system with fins, which can possibly be utilized to drive a rotary desiccant cooling system. The results revealed that the useful thermal energy and net electrical gains from the optimal designs are much greater than those obtained from the two baseline cases. 
Kabeel et al. (2018) studied firstly the performance of ordinary finned SAH and after that modifying the entrance region covering it with glass lid as opposed to opaque or steel lid. Additionally, guide blades were placed in the entrance area to make sure good air distribution over the absorber surface. The results revealed good augmentation in both the efficiency as well as the air temperature difference. Shalini Rai (2018) investigated theoretically thermohydraulic effect on offset finned absorber solar air heater. Results indicate that the thermal efficiency increases continuously with increase in fluid mass flow rate, whereas thermohydraulic efficiency increases up to an inception value of fluid mass flow rate, attains maximum and then decreases sharply for a given fin spacing and fin height. Khanna et al. (2018) carrying out the optimization of Finned-PV-PCM system to keep PV temperature low during operation for different solar irradiance levels and how it is affected with spacing between successive fins, fin length and fin thickness. Study concluded that larger length and thickness of fins can preserve the PV at lower temperature level.

Priyam and Chand (2018) theoretically investigated the thermal and thermohydraulic performance of a single pass flat plate solar air heater for calculating the various values of wavelength and amplitude. It has been found that increase in wavelength and amplitude of the wavy fin drastically increased the collector efficiency factor, collector heat removal factor, thermal efficiency, effective efficiency and rise in temperature at the lower mass flow rate. The results reveal an excellent enhancement in the thermohydraulic as well as thermal performance with the modified solar air heating system. Jafari Mosleh et al. (2019) experimentally as well as numerically explored using pulsating heat pipes (PHPs) as replacement for fins in a typical air-cooled heat exchanger. The outcomes showed that making use of pulsating heat pipelines as fins have a considerable impact on enhancing the heat transfer. The total heat transfer coefficient was enhanced by $310 \%$. This enhancement was roughly $263 \%$ for the forced convection condition.

Saravanakumar et al. (2019) analysed the thermohydraulic performance improvement of solar air heater $(\mathrm{SAH})$ with various design configurations. A mathematical model is executed to examine the effect of absorber plate with arc-shaped rib roughened barrier with fins as well as baffles on the efficient and thermal efficiency of SAH. The suggested design boosts the energy and effective effectiveness by $28.3 \%$ and $27.1 \%$ compared to arc shape rib roughened solar air heating system. It was additionally concluded that lower baffle width and length values provides maximum effective efficiency at greater mass flow rates. Table 1 represents some important previous studies on with and without fins solar air heater.

\section{COMPARATIVE STUDY}

The ambient temperature has major impact on the performance of the solar air heater. As per the study, the solar air heater with fins is approximately $8.5 \%$ more efficient than the without fins during the natural convection and the solar air heater with fins is near by $10.45 \%$ more efficient than without fins during the forced convection as shown in figure 1 . The working of the solar air heater is dependent on various factors like intensity of solar radiation, direction of wind and its speed, atmospheric conditions, ambient temperature.

The main limitation of solar collectors is lower thermal efficiency due to low heat transfer coefficient between the absorber plate and the flowing air because of poor thermal conductivity. Various methods \& suggestions are applied to enhance the heat transfer coefficient between the absorber plate and flow of air. Various investigations related to this carried out in many ways in which one of the effective ways is to enhance the heat transfer area to increase the turbulence inside the flowing channel through fins or extended surfaces. It is also found in this study the overall efficiency can be increased by increase in air mass flow rate in which double pass is found to be more efficient than the single pass as shown in figure 2 for the same mass flow rate. Figure. 3 shows that the variation of thermal efficiency with mass flow rate for porous SAH and non-porous SAH and found the porous SAH has highest thermal efficiency as compared than nonporous SAH.

Figs $4 \& 5$ show the variation of the thermal efficiency with air mass flow rate. It is found from both figures that the thermal efficiency increases with increasing air mass flow rate and depth ratio. This is because the heat transfer rate is directly proportional to the air massflow rate. At a given air mass flow rate, the increase of the number and height of fins causing increase of heat transfer surface area results in the increase of heat transfer rate. Therefore, thermal efficiency also increases as the number and height of fins increase. Fig. 6 shows that the effect of fin height on thermal efficiency and found that the maximum thermal efficiency for fin height is $8.0 \mathrm{~cm}$ as compared $5.0 \mathrm{~cm}$.

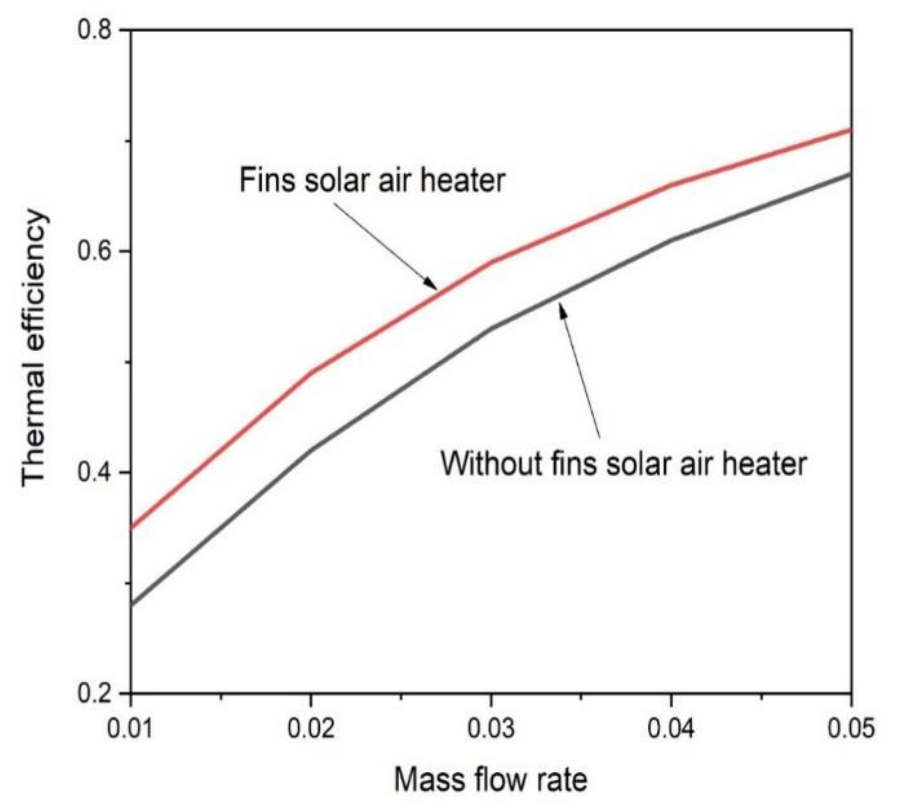

Fig. 1 Variation of thermal efficiency with mass flow rate for fins SAH

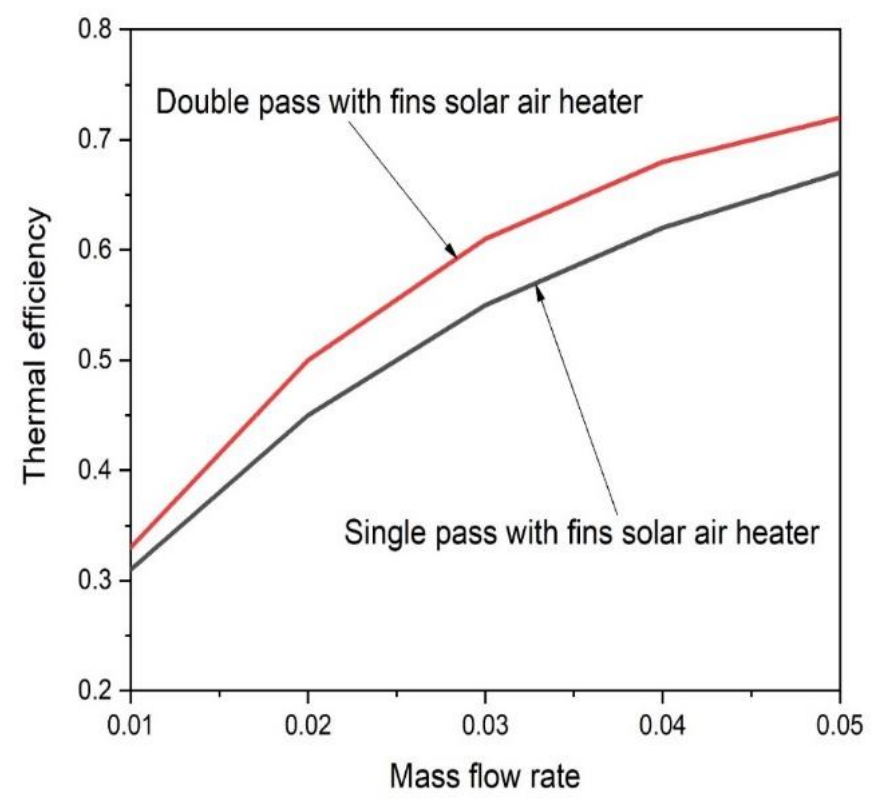

and without SAH [Source: Indrajit (1985)]

Fig. 2 Variation of thermal efficiency with mass flow rate for double pass with fins SAH and single pass with fins SAH [Source: Kumar and Rosen (2011)] 
Table 1 Some important previous studied on with and without fins solar air heater.

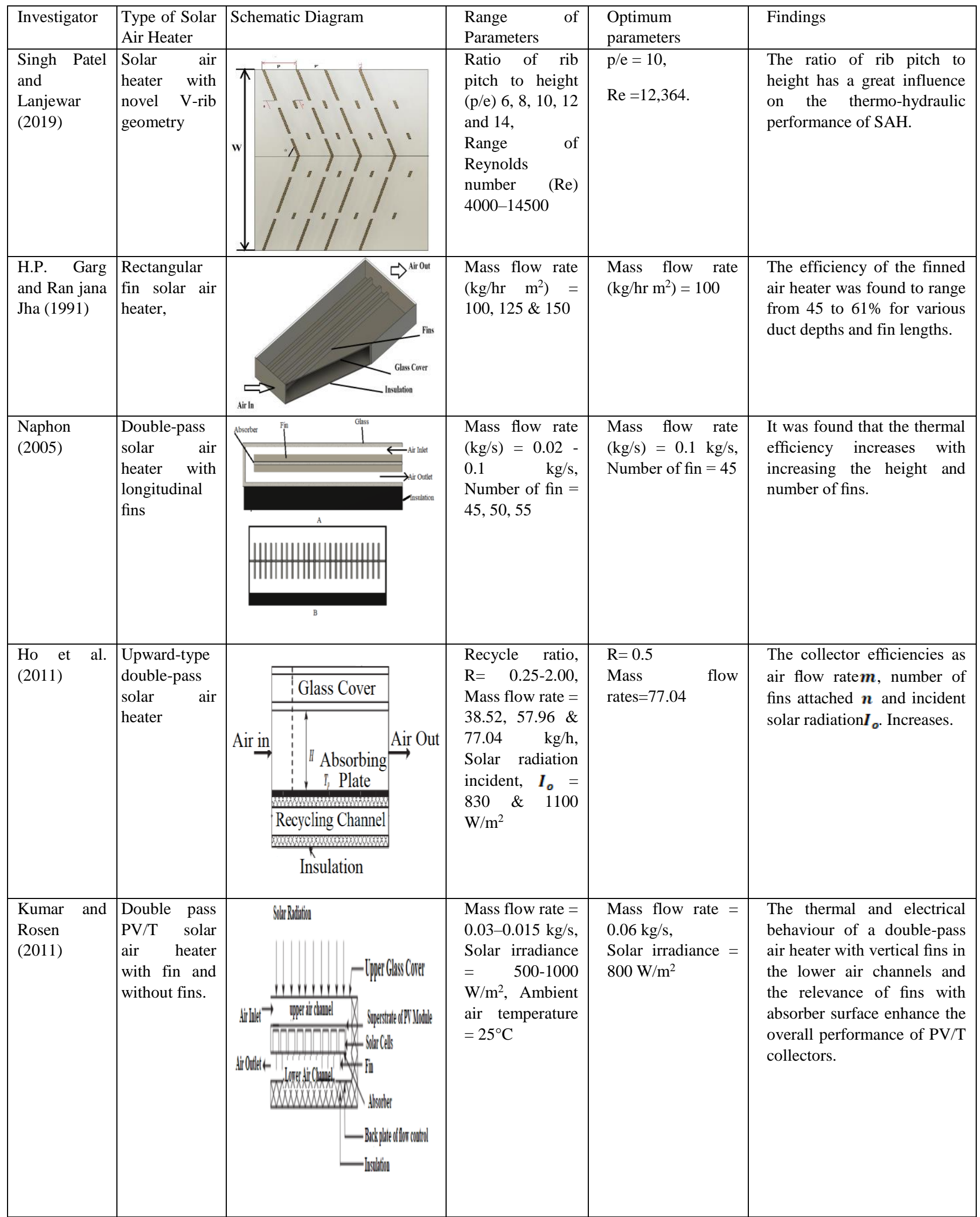




\begin{tabular}{|c|c|c|c|c|c|}
\hline Investigator & $\begin{array}{l}\text { Type of } \\
\text { Solar Air } \\
\text { Heater }\end{array}$ & Schematic Diagram & $\begin{array}{ll}\text { Range } & \text { of } \\
\text { Parameters }\end{array}$ & $\begin{array}{l}\text { Optimum } \\
\text { parameters }\end{array}$ & Findings \\
\hline $\begin{array}{l}\text { Ho et al. } \\
(2012)\end{array}$ & $\begin{array}{l}\text { Double-pass } \\
\text { solar air } \\
\text { heater with } \\
\text { fins } \\
\text { and baffles }\end{array}$ & Cipper subchannel & $\begin{array}{l}\text { Mass flow rate } \\
=0.01, \quad 0.015 \text {, } \\
0.02 \mathrm{~kg} / \mathrm{s}, \text { Solar } \\
\text { radiation } \\
\text { incident, } I_{o}= \\
830 \& 1100 \\
\mathrm{~W} / \mathrm{m}^{2}, \text { Number } \\
\text { of fins attached, } \\
\mathrm{n}=12 \& 24\end{array}$ & $\begin{array}{l}\text { Mass flow rate } \\
=0.01 \mathrm{~kg} / \mathrm{s}, \mathrm{n}=12 \\
\text { For } \boldsymbol{I}_{o}=830 \& \\
1100 \mathrm{~W} / \mathrm{m}^{2} \\
\text { Collector } \\
\text { Efficiency, } \boldsymbol{\eta}= \\
76.17 \% \& 81.27 \%\end{array}$ & $\begin{array}{l}\text { Application of the concept of } \\
\text { double-pass in the design of } \\
\text { a double-pass solar air heater } \\
\text { with fins attached is } \\
\text { technically and economically } \\
\text { feasible. }\end{array}$ \\
\hline $\begin{array}{l}\text { Bhattacharyy } \\
\text { a et al. (2017) }\end{array}$ & $\begin{array}{l}\text { Finned Plate } \\
\text { Air Heating } \\
\text { Solar } \\
\text { Collector }\end{array}$ & 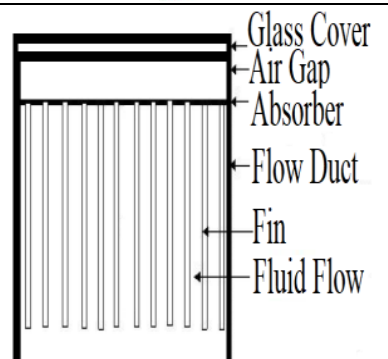 & $\begin{array}{l}\text { Mass flow rate }= \\
100-150 \\
\mathrm{Kg} / \mathrm{hr} / \mathrm{m}^{2} \\
\text { Number of Fins } \\
=50 \& 80 \\
\text { Fin Thickness }= \\
2-3 \mathrm{~mm} \\
\mathrm{H} / \mathrm{D} \text { ratios }=0.4 \text {, } \\
0.6 \& 0.8\end{array}$ & $\begin{array}{l}\text { Mass flow rate }= \\
0.01 \mathrm{Kg} / \mathrm{s} \\
\text { Number of Fins }= \\
80 \\
\text { Fin Thickness }=2 \\
\mathrm{~mm} \\
\mathrm{H} / \mathrm{D} \text { ratios }=0.6\end{array}$ & $\begin{array}{l}\text { Outlet air temperature first } \\
\text { increases and then decreases } \\
\text { with number of fins. Pressure } \\
\text { drop also increases with } \\
\text { number of fins and fin } \\
\text { height. }\end{array}$ \\
\hline
\end{tabular}




\begin{tabular}{|c|c|c|c|c|c|}
\hline Investigator & $\begin{array}{l}\text { Type of Solar } \\
\text { Air Heater }\end{array}$ & Schematic Diagram & $\begin{array}{l}\text { Range of } \\
\text { Parameters }\end{array}$ & $\begin{array}{l}\text { Optimum } \\
\text { parameters }\end{array}$ & Findings \\
\hline $\begin{array}{l}\text { Rai et al. } \\
(2017)\end{array}$ & $\begin{array}{l}\text { Offset finned } \\
\text { absorber solar } \\
\text { air heater }\end{array}$ & $\begin{array}{l}\text { Isc } \\
\text { outlet }\end{array}$ & $\begin{array}{l}\text { Mass flow rate } \\
\text { of air in } \mathrm{kg} / \mathrm{s}= \\
0.0139-0.083 \\
\mathrm{~kg} / \mathrm{s}, \quad \text { Solar } \\
\text { insolation, } \mathrm{I}_{\mathrm{o}}= \\
750 \text { \& } 900 \\
\mathrm{~W} / \mathrm{m}^{2}\end{array}$ & $\begin{array}{l}\text { Mass flow rate of } \\
\text { air in kg/s = } \\
0.0139 \mathrm{~kg} / \mathrm{s} \\
\text { Solar insolation, Io } \\
=750 \mathrm{~W} / \mathrm{m}^{2} \\
\text { Offset fin height, } \mathrm{h}_{\mathrm{f}} \\
=0.038 \mathrm{~m}\end{array}$ & $\begin{array}{l}\text { It is found that attaching } \\
\text { offset fins below the } \\
\text { absorber plate at lower mass } \\
\text { flow rate can lead to } \\
\text { appreciable enhancement of } \\
106.9 \% \text { and } 67.38 \% \\
\text { respectively for the thermal } \\
\text { and thermohydraulic } \\
\text { efficiencies. }\end{array}$ \\
\hline $\begin{array}{l}\text { Bai et al. } \\
(2018)\end{array}$ & $\begin{array}{l}\text { Solar thermal } \\
\text { storage heater } \\
\text { assembled } \\
\text { with } \\
\text { finned heat } \\
\text { pipe and } \\
\text { collective } \\
\text { vacuum tubes }\end{array}$ & 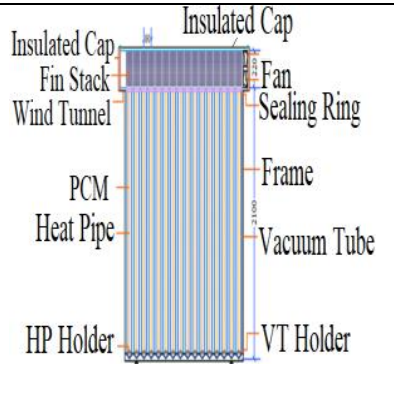 & $\begin{array}{l}\text { Elevation } \\
\text { Angles }=50^{\circ}, \\
60^{\circ}, 70^{\circ} \text { and } \\
80^{\circ} . \\
\text { Solar radiation } \\
\text { incident }=812, \\
880, \quad 920 \text { and } \\
980 \mathrm{~W} / \mathrm{m}^{2} \text {. }\end{array}$ & $\begin{array}{l}\text { Elevation Angles = } \\
60^{\circ}, \quad \text { Solar } \\
\text { radiation incident } \\
=998 \mathrm{~W} / \mathrm{m}^{2}\end{array}$ & $\begin{array}{l}\text { It is concluded that the } \\
\text { STSHE should be placed } \\
\text { toward the south at an } \\
\text { elevation angle of } 60^{\circ} \text { to the } \\
\text { ground in July and August } \\
\text { though the heat storage } \\
\text { performance of the } \\
\text { equipment improved } \\
\text { significantly as the solar } \\
\text { radiation increased. }\end{array}$ \\
\hline $\begin{array}{l}\text { Kabeel et } \\
\text { al. (2018) }\end{array}$ & \begin{tabular}{|l|} 
single-pass sola \\
air \\
heater
\end{tabular} & 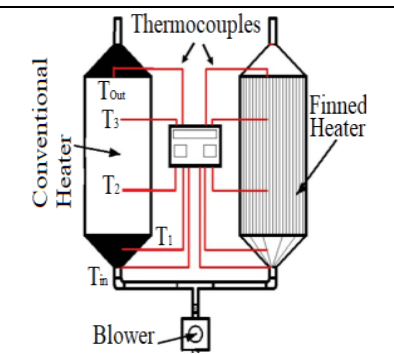 & $\begin{array}{l}\text { Mass flow rate } \\
\text { of air }=0.013 \text {, } \\
0.022,0.031 \text { and } \\
0.04 \mathrm{~kg} / \mathrm{s}, \text { Fin } \\
\text { Heights }=3,5 \\
\text { and } 8 \mathrm{~cm} .\end{array}$ & $\begin{array}{l}\text { Mass flow rate }= \\
0.04 \mathrm{~kg} / \mathrm{s}, \quad \text { Fin's } \\
\text { height }=8 \mathrm{~cm},\end{array}$ & $\begin{array}{l}\text { The results showed good } \\
\text { enhancement in both the } \\
\text { efficiency and the air } \\
\text { temperature difference. }\end{array}$ \\
\hline $\begin{array}{l}\text { Priyam and } \\
\text { Chand } \\
(2018)\end{array}$ & $\begin{array}{l}\text { Wavy } \\
\text { finned } \\
\text { solar air } \\
\text { heater }\end{array}$ & Glass Cover & $\begin{array}{l}\text { Mass flow rate = } \\
0.0138-0.834 \\
\mathrm{~kg} / \mathrm{s}, \\
\text { Amplitude = } \\
0.5-2.5 \quad \mathrm{~cm}, \\
\text { Wavelength } \\
\lambda=3,7,15, \\
20 \mathrm{~cm}\end{array}$ & $\begin{array}{l}\text { For Mass flow rate } \\
=0.061 \mathrm{~kg} / \mathrm{s}, \\
\text { Amplitude }=2.5 \\
\mathrm{~cm} \text { Wavelength } \lambda= \\
3 \mathrm{~cm}\end{array}$ & $\begin{array}{l}\text { The results show a great } \\
\text { enhancement in the thermal } \\
\text { and thermohydraulic } \\
\text { performance with the } \\
\text { modified solar air heater. }\end{array}$ \\
\hline $\begin{array}{l}\text { Saravanaku } \\
\text { mar et al. } \\
(2019)\end{array}$ & $\begin{array}{l}\text { Arc shaped sola } \\
\text { air heater } \\
\text { integrated with } \\
\text { fins and baffles }\end{array}$ & a) Acr shaper roghhnoss & $\begin{array}{l}\text { Reynolds } \\
\text { Number (Re) } \\
2900-17000, \\
\text { Width of the } \\
\text { Baffle (W }) \\
0.005-0.015 \mathrm{~m}, \\
\text { Length of the } \\
\text { Baffle (LB) 0.2- } \\
0.4 \mathrm{~m} \text {, } \\
\text { Number of fins } \\
2-10 \text {, } \\
\text { Solar Intensity, } \\
800 \mathrm{~W} / \mathrm{m}^{2}\end{array}$ & $\begin{array}{l}\text { Width of the } \\
\text { Baffle }\left(\mathrm{W}_{\mathrm{B}}\right) 0.005 \\
\text { enhances the } \\
\text { performance by } \\
27.1 \% \text { Width of } \\
\text { the Baffle }\left(\mathrm{W}_{\mathrm{B}}\right) \\
0.015 \mathrm{~m} \text { for the } \\
\text { maximum } \\
\text { enhancement in } \\
\text { thermal efficiency } \\
\text { by } 28.3 \% \text {, Length } \\
\text { of the Baffle (LB) } \\
0.2 \mathrm{~m}\end{array}$ & $\begin{array}{l}\text { It is concluded that SAH } \\
\text { with arc shaped rib } \\
\text { roughened absorber plate } \\
\text { integrated fins with baffles } \\
\text { have better performance. At } \\
\text { lower mass flow rates, } \\
\text { increasing the number fins } \\
\text { improves the effective } \\
\text { efficiency and at higher mass } \\
\text { flow rates it reverses the } \\
\text { trend due to higher pressure } \\
\text { drop. }\end{array}$ \\
\hline
\end{tabular}




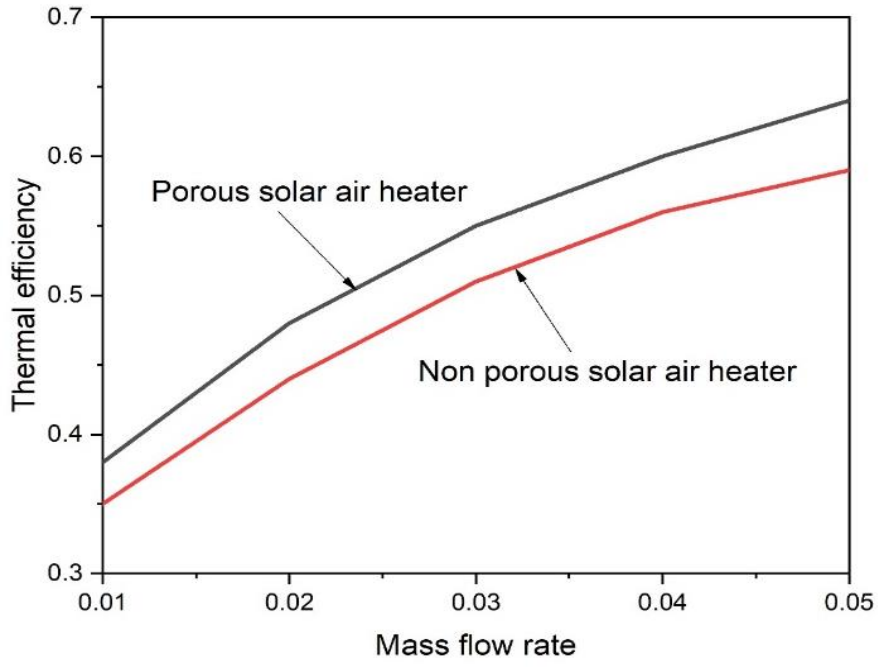

Fig. 3 Variation of thermal efficiency with mass flow rate for porous SAH and non-porous SAH [Source: Indrajit (1985)]

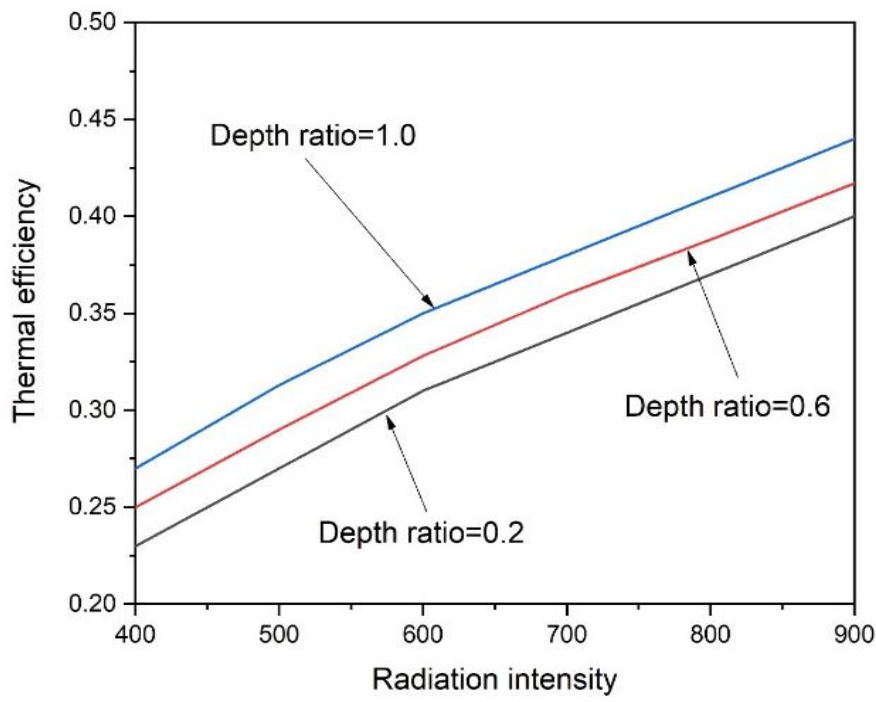

Fig. 4 Variation of thermal efficiency with radiation intensity for different depth ratio [Source: Hosseini et al. (2017)]

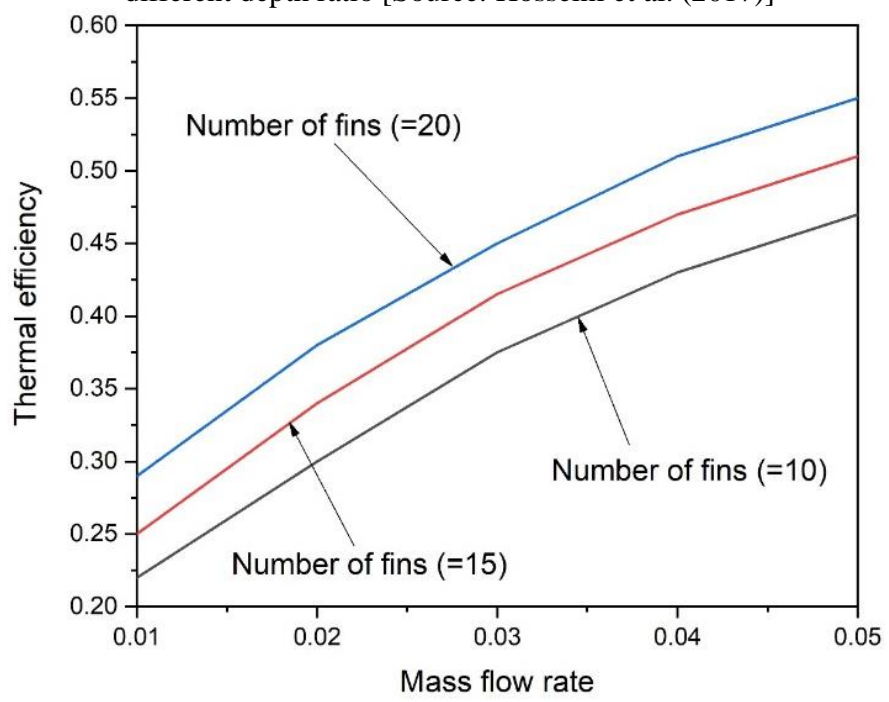

Fig. 5 Variation of thermal efficiency with air mass flow rate for different number of fins [Source: Naphon (2005)]

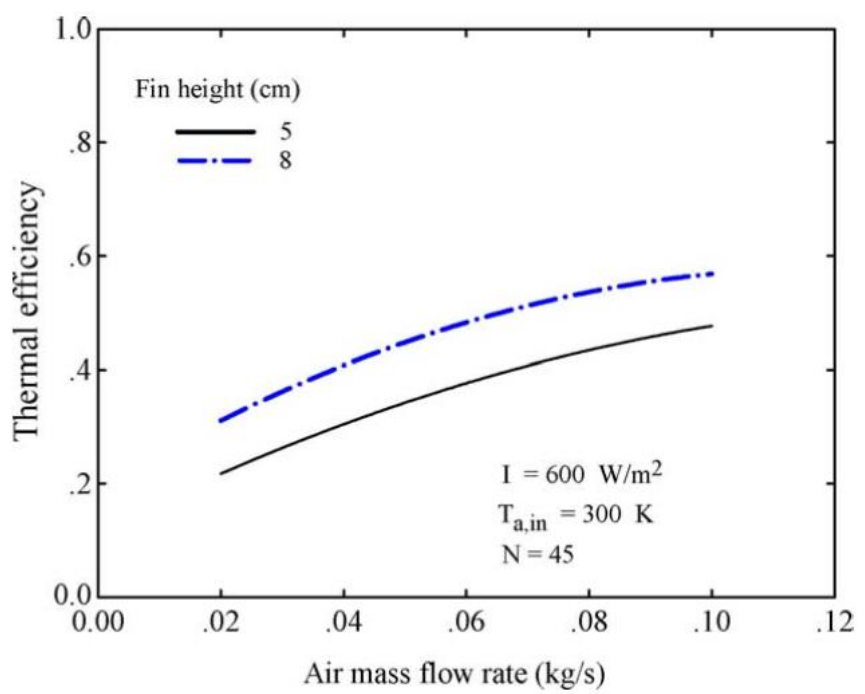

Fig. 6 Effect of Fin height on Thermal efficiency [Source: Naphon (2005)]

\section{CONCLUSION}

This work presented a comprehensive review of performance analysis of solar air collector with and without fins. On the source of the comprehensive literature review and comparative study of fins and without fins SAH.

- The experiments on simple and non-porous absorber SAHs indicated that adding fins is beneficial only at smaller flow rate. The collector efficiency indicated a strong dependence on the fin length and number of fins.

- The efficiency of the finned air heater was found to range from 45 to $61 \%$ for various duct depths and fin lengths. The outlet air temperature for the air heater with fins is greater than that of a conventional air heater.

- The concept of double-flow in the design of a solar air heater with fins attached is technically and economically feasible. The thermal efficiency increases with increasing the height and number of fins.

- The entropy generation is inversely proportional to the height and number of fins. Recycle effect can enhance collector efficiency on the recyclic device, especially for the case that the distance between tubes and number of fins attached is smaller. Porous media between the fins in the proposed design increases the rate of heat transfer between the air and the bed.

- The maximum difference between the outlet and inlet air temperature for the 2.0, 4.0, 6.0 fins $\mathrm{SAH}$ was $53.3^{\circ} \mathrm{C}, 52.9^{\circ} \mathrm{C}$ and $62.1^{\circ} \mathrm{C}$, respectively. The thermal efficiency of the 6.0 fins $\mathrm{SAH}$ was compared with some of the reported ones.

- The double pass v-corrugated plate solar air heater is $9.3-11.9 \%$ more efficient compared to the double passfinned plate SAH. It was also indicated that the peak values of the thermohydraulic efficiencies of the double pass-finned and v-corrugated plate SAHs were obtained when the mass flow rates of the flowing air equal 0.0125 and $0.0225 \mathrm{~kg} / \mathrm{s}$, respectively. An internal finned configuration tube collector has higher efficiency than plain tube collector. 
- The efficiency improvement is nearly $4.5 \%$, and further for a long run for the internal finned tube collectors. The maximum daily efficiency of the ordinary finned SAH was $43.1 \%$ at $0.04 \mathrm{~kg} / \mathrm{s}$ and $8 \mathrm{~cm}$ fins' height.

- For the modified finned SAH, the highest daily efficiency was $57 \%$ at $0.04 \mathrm{~kg} / \mathrm{s}$ with fins' height of 8 $\mathrm{cm}$. While for the conventional SAH, the highest daily efficiency was about $32 \%$.

- The thermal efficiency increases continuously with increase in fluid mass flow rate, whereas thermohydraulic efficiency increases up to an inception value of fluid mass flow rate, attains a maximum and then decreases sharply for a given fin spacing and fin height.

\section{NOMENCLATURE}

$\begin{array}{ll}\mathrm{Re} & \text { Reynolds number } \\ \mathrm{Nu} & \text { Nusselt number } \\ f & \text { Friction factor } \\ m & \text { Mass flow rate, } \mathrm{kg} / \mathrm{s} \\ \text { Subscripts } & \\ \text { SAH } & \text { Solar air heater } \\ \mathrm{CFD} & \text { Computational fluid dynamics }\end{array}$

\section{REFERENCES}

Aboghrara, A. M., Baharudin, B. T. H. T., Alghoul, M. A., Adam, N. M., Hairuddin, A. A., and Hasan, H. A. (2017), "Performance analysis of solar air heater with jet impingement on corrugated absorber plate." Review of. Case Studies in Thermal Engineering 10:111-20. https://doi: 10.1016/j.csite.2017.04.002.

Ahmad Fudholi, K. S., Mohd Hafidz Ruslan, Mohd Yusof Othman. (2013a), "Performance and cost benefits analysis of double-pass solar collector with and without fins." Review of. Energy Conversion and Management 76:8-19.

https://doi: 10.1016/j.enconman.2013.07.015.

Ahmad Fudholi, K. S., Mohd Yusof Othman, Mohd Hafidz Ruslan, B. Bakhtyar. (2013b), "Energy analysis and improvement potential of finned double-pass solar collector." Review of. Energy Conversion and Management 75:234-40.

https://doi: 10.1016/j.enconman.2013.06.021.

Ali Daliran, Y. A. (2018), "Theoretical and experimental research on effect of fins attachment on operating parameters and thermal efficiency of solar air collector." Review of. Information processing in agriculture 5:411-21.

https://doi: 10.1016/j.inpa.2018.07.004.

Ansari, M., and Bazargan, M. (2018), "Optimization of flat plate solar air heaters with ribbed surfaces." Review of. Applied Thermal Engineering 136:356-63.

https://doi: 10.1016/j.applthermaleng.2018.02.099

Bai, Y., He, X., Liu, Y., Duan, J., Wang, Y., and Han, X. (2018), "Experimental investigation of a solar thermal storage heater assembled with finned heat pipe and collective vacuum tubes." Review of. Energy Conversion and Management 166:463-73.

https://doi: 10.1016/j.enconman.2018.04.034.

Bhattacharyya, T., Anandalakshmi, R., and Srinivasan, K. (2017), "Heat Transfer Analysis on Finned Plate Air Heating Solar Collector for its Application in Paddy Drying." Review of. Energy Procedia 109:353-60.

https://doi: 10.1016/j.egypro.2017.03.086.

C.D. Ho, H. M. Y., T.W. Cheng, T.C. Chen, R.C. Wang. (2009), "The influences of recycle on performance of baffled double-pass flat-plate solar air heaters with internal fins attached." Review of. Applied Energy 86 (9):1470-8.

https://doi: 10.1016/j.apenergy.2008.12.013.

Chabane, F., Moummi, N., and Benramache, S. (2014), "Experimental study of heat transfer and thermal performance with longitudinal fins of solar air heater." Review of. J Adv Res 5 (2):183-92.

https://doi: 10.1016/j.jare.2013.03.001.

Cuzminschi, M., Gherasim, R., Girleanu, V., Zubarev, A., and Stamatin, I. (2018), "Innovative thermo-solar air heater." Review of. Energy and Buildings 158:964-70. https://doi: 10.1016/j.enbuild.2017.10.082.

El-khawajah, M. F., Aldabbagh, L. B. Y., and Egelioglu, F. (2011), "The effect of using transverse fins on a double pass flow solar air heater using wire mesh as an absorber." Review of. Solar Energy 85 (7):1479-87.

https://doi: 10.1016/j.solener.2011.04.004.

El-Sebaii, A. A., Aboul-Enein, S., Ramadan, M. R. I., Shalaby, S. M., and Moharram, B. M. (2011), "Thermal performance investigation of double pass-finned plate solar air heater." Review of. Applied Energy 88 (5):1727-39.

https://doi: 10.1016/j.apenergy.2010.11.017.

Evangelos Bellos, C. T., Dimitrios Tsimpoukis. (2018), "Optimum number of internal fins in parabolic trough collectors." Review of. Applied Thermal Engineering 137:669-77. https://doi: 10.1016/j.applthermaleng.2018.04.037.

Evangelos Bellos, C. T., Ilias Daniil, Kimon A. Antonopoulos. (2017), "The impact of internal longitudinal fins in parabolic trough collectors operating with gases." Review of. Energy Conversion and Management 135:35-54.

https://doi: 10.1016/j.enconman.2016.12.057.

Fakoor Pakdaman, M., Lashkari, A., Basirat Tabrizi, H., and Hosseini, R. (2011), "Performance evaluation of a natural-convection solar airheater with a rectangular-finned absorber plate." Review of. Energy Conversion and Management 52 (2):1215-25. https://doi: 10.1016/i.enconman.2010.09.017.

Fan, W., Kokogiannakis, G., and Ma, Z. (2018), "A multi-objective design optimisation strategy for hybrid photovoltaic thermal collector (PVT)-solar air heater (SAH) systems with fins." Review of. Solar Energy 163:315-28. https://doi: 10.1016/j.solener.2018.02.014.

Fan, W., Kokogiannakis, G., Ma, Z., and Cooper, P. (2017), "Development of a dynamic model for a hybrid photovoltaic thermal collector - Solar air heater with fins." Review of. Renewable Energy 101:816-34.

https://doi: 10.1016/j.renene.2016.09.039.

Farkas, M. A. A.-N. I. (2018), "Thermal efficiency of vertical and horizontal finned solar collector integrated with forced air circulation dryer for Apple as a sample." Review of. Drying Technology An International Journal. https://doi: 10.1080/07373937.2018.1488260. 
H.P. Garg, and Ran jana Jha , C. C., and Gouri Datta. (1991), "Theoretical analysis on a new finned type solar air heater." Review of. Energy 16 (10):1231-8. https://doi.org/10.1016/0360-5442(91)90152-C

Heydari, A., and Mesgarpour, M. (2018), "Experimental analysis and numerical modeling of solar air heater with helical flow path." Review of. Solar Energy 162:278-88.

https://doi: 10.1016/j.solener.2018.01.030.

Ho, C.-D., Chang, H., Wang, R.-C., and Lin, C.-S. (2012), "Performance improvement of a double-pass solar air heater with fins and baffles under recycling operation." Review of. Applied Energy 100:155-63.

https://doi: 10.1016/j.apenergy.2012.03.065.

Ho, C.-D., Yeh, H.-M., and Chen, T.-C. (2011), "Collector efficiency of upward-type double-pass solar air heaters with fins attached." Review of. International Communications in Heat and Mass Transfer 38 (1):49-56.

https://doi: 10.1016/j.icheatmasstransfer.2010.09.015.

Ho, C. D., and Chen, T. C. (2008), "Collector efficiency improvement of recyclic double-pass sheet-and-tube solar water heaters with internal fins attached." Review of. Renewable Energy 33 (4):655-64.

https://doi: 10.1016/j.renene.2007.04.002.

Hosseini, S. S., Ramiar, A., and Ranjbar, A. A. (2017), "Numerical investigation of rectangular fin geometry effect on solar chimney." Review of. Energy and Buildings 155:296-307.

https://doi: 10.1016/j.enbuild.2017.09.017.

Indrajit, N. K. B. a. H. P. G. (1985), "An experimental study on a finned type and non-porous type solar air heater with a solar simulator " Review of. Energy Conversion and Management 25 (2):135-8. https://doi.org/10.1016/0196-8904(85)90023-8

Jafari Mosleh, H., Bijarchi, M. A., and Shafii, M. B. (2019), "Experimental and numerical investigation of using pulsating heat pipes instead of fins in air-cooled heat exchangers." Review of. Energy Conversion and Management 181:653-62.

https://doi: 10.1016/j.enconman.2018.11.081.

Jia, B., Liu, F., and Wang, D. (2019), "Experimental study on the performance of spiral solar air heater." Review of. Solar Energy 182:16-21.

https://doi: 10.1016/j.solener.2019.02.033.

Jin, D., Quan, S., Zuo, J., and Xu, S. (2019), "Numerical investigation of heat transfer enhancement in a solar air heater roughened by multiple V-shaped ribs." Review of. Renewable Energy 134:78-88.

https://doi: 10.1016/j.renene.2018.11.016.

Kabeel, A. E., Hamed, M. H., Omara, Z. M., and Kandeal, A. W. (2018), "Influence of fin height on the performance of a glazed and bladed entrance single-pass solar air heater." Review of. Solar Energy 162:410-9.

https://doi: 10.1016/j.solener.2018.01.037.

Kabeel, A. E., Khalil, A., Shalaby, S. M., and Zayed, M. E. (2017), "Improvement of thermal performance of the finned plate solar air heater by using latent heat thermal storage." Review of. Applied Thermal Engineering 123:546-53.

https://doi: 10.1016/j.applthermaleng.2017.05.126.
Kasperski, J., and Nemś, M. (2013), "Investigation of thermo-hydraulic performance of concentrated solar air-heater with internal multiple-fin array." Review of. Applied Thermal Engineering 58 (1-2):411-9. https://doi: 10.1016/j.applthermaleng.2013.04.018.

Kashyap, K., Thakur, R., Kumar, A. (2019), "Mathematical simulation of performance evaluation of different types of baffle shapes solar air heater." JP Journal of Heat and Mass Transfer 16(2):221-243. https://doi.org/10.17654/HM016020221.

Khanna, S., Reddy, K. S., and Mallick, T. K. (2018), "Optimization of finned solar photovoltaic phase change material (finned $\mathrm{pv} \mathrm{pcm}$ ) system." Review of. International Journal of Thermal Sciences 130:313-22.

https://doi: 10.1016/j.ijthermalsci.2018.04.033.

Kumar, S., Thakur, R., Gandotra, N., Aggarwal, S., Singhy, A., Maithani, R., and Kumar, A. (2020), "Prediction of heat transfer and pressure drop in helically perforated twisted tape heat exchanger tube using fuzzy logic." JP Journal of Heat and Mass Transfer 19(1):175184.

https://doi.org/10.17654/HM019010175.

Kumar, D., and Premachandran, B. (2019), "Effect of atmospheric wind on natural convection based solar air heaters." Review of. International Journal of Thermal Sciences 138:263-75.

https://doi: 10.1016/j.ijthermalsci.2018.12.010.

Kumar, R., and Chand, P. (2017), "Performance enhancement of solar air heater using herringbone corrugated fins." Review of. Energy 127:271-9.

https://doi: 10.1016/j.energy.2017.03.128.

Kumar, R., and Rosen, M. A. (2011), "Performance evaluation of a double pass PV/T solar air heater with and without fins." Review of. Applied Thermal Engineering 31 (8-9):1402-10. https://doi: 10.1016/j.applthermaleng.2010.12.037.

Mahmood, A. J., Aldabbagh, L. B. Y., and Egelioglu, F. (2015), "Investigation of single and double pass solar air heater with transverse fins and a package wire mesh layer." Review of. Energy Conversion and Management 89:599-607.

https://doi: 10.1016/j.enconman.2014.10.028.

Mohamed S.Yousef , H. H., S. Kodama, and H. Sekiguchi , and (2019), "An experimental study on the performance of single slope solar still integrated with a pcm-based pin-finned heat sink " Review of. Energy Procedia 156:100-4. https://doi.org/10.1016/j.egypro.2018.11.102.

Mohammadi, K., and Sabzpooshani, M. (2013), "Comprehensive performance evaluation and parametric studies of single pass solar air heater with fins and baffles attached over the absorber plate." Review of. Energy 57:741-50.

https://doi: 10.1016/j.energy.2013.05.016.

Murugan, M., Vijayan, R., Saravanan, A., and Jaisankar, S. (2019), "Performance enhancement of centrally finned twist inserted solar collector using corrugated booster reflectors." Review of. Energy 168:858-69.

https://doi: 10.1016/j.energy.2018.11.134.

Mzad, H., Bey, K., and Khelif, R. (2019), "Investigative study of the thermal performance of a trial solar air heater." Review of. Case Studies in Thermal Engineering 13:100373.

https://doi: $10.1016 /$ i.csite.2018.100373 
Naphon, P. (2005), "On the performance and entropy generation of the double-pass solar air heater with longitudinal fins." Review of. Renewable Energy 30 (9):1345-57. https://doi: 10.1016/j.renene.2004.10.014.

Nemś, M., and Kasperski, J. (2016), "Experimental investigation of concentrated solar air-heater with internal multiple-fin array." Review of. Renewable Energy 97:722-30.

https://doi: 10.1016/j.renene.2016.06.038.

Nwosu, N. P. (2010), "Employing exergy-optimized pin fins in the design of an absorber in a solar air heater." Review of. Energy 35 (2):571-5.

https://doi: 10.1016/j.energy.2009.10.027.

Omojaro, A. P., and Aldabbagh, L. B. Y. (2010), "Experimental performance of single and double pass solar air heater with fins and steel wire mesh as absorber." Review of. Applied Energy 87 (12):375965.

https://doi: 10.1016/j.apenergy.2010.06.020.

Priyam, A., and Chand, P. (2016), "Thermal and thermohydraulic performance of wavy finned absorber solar air heater." Review of. Solar Energy 130:250-9.

https://doi: 10.1016/j.solener.2016.02.030.

Priyam, A., and Chand, P. (2018), "Effect of wavelength and amplitude on the performance of wavy finned absorber solar air heater." Review of. Renewable Energy 119:690-702.

https://doi: 10.1016/j.renene.2017.12.010.

Rafael GustavoSchreibera, L. (2018), "Manufacture of absorber fins for solar collector using incremental sheet forming." Review of. Journal of Material research and Technology.

https://doi: 10.1016/j.jmrt.2018.07.018.

Rai, S., Chand, P., and Sharma, S. P. (2017), "An analytical investigations on thermal and thermohydraulic performance of offset finned absorber solar air heater." Review of. Solar Energy 153:25-40. https://doi: 10.1016/j.solener.2017.05.039.

Ramanan, M. D. B. M. V. (2016), "Experimental Analysis on the Performance of A Solar Flat Plate Water Heater With and Without Internal Fins." Review of. International Journal of Ambient Energy 38 (6):582-9.

https://doi: $10.1080 / 01430750.2016 .1155496$.

Saravanakumar, P. T., Somasundaram, D., and Matheswaran, M. M. (2019), "Thermal and thermo-hydraulic analysis of arc shaped rib roughened solar air heater integrated with fins and baffles." Review of. Solar Energy 180:360-71.

https://doi: 10.1016/j.solener.2019.01.036.
Shalini Rai, P. C., S.P. Sharma. (2018), "Evaluation of thermo hydraulic effect on offset finned absorber solar air heater." Review of. Renewable Energy 125:39-54.

https://doi: doi.org/10.1016/j.renene.2018.01.110.

Singh, A. P., and Singh, O. P. (2018a), "Performance enhancement of a curved solar air heater using CFD." Review of. Solar Energy 174:55669.

https://doi: 10.1016/j.solener.2018.09.053.

Singh Bisht, V., Kumar Patil, A., and Gupta, A. (2018), "Review and performance evaluation of roughened solar air heaters." Review of. Renewable and Sustainable Energy Reviews 81:954-77.

https://doi: 10.1016/j.rser.2017.08.036.

Singh, I., and Singh, S. (2018b), "A review of artificial roughness geometries employed in solar air heaters." Review of. Renewable and Sustainable Energy Reviews 92:405-25.

https://doi: 10.1016/j.rser.2018.04.108.

Singh Patel, S., and Lanjewar, A. (2019), "Experimental and numerical investigation of solar air heater with novel V-rib geometry." Review of. Journal of Energy Storage 21:750-64. https://doi: 10.1016/j.est.2019.01.016.

Thapa S, Samir S, Kumar K, Singh S. (2021), "A review study on the active methods of heat transfer enhancement in heat exchangers using electroactive and magnetic materials." Materials Today: Proceedings. In press

https://doi.org/10.1016/j.matpr.2021.01.382.

Wadhawan, A., Dhoble, A. S., and Gawande, V. B. (2018), "Analysis of the effects of use of thermal energy storage device (TESD) in solar air heater." Review of. Alexandria Engineering Journal 57 (3):1173-83. https://doi: 10.1016/j.aej.2017.03.016.

Yang, M., Yang, X., Li, X., Wang, Z., and Wang, P. (2014), "Design and optimization of a solar air heater with offset strip fin absorber plate." Review of. Applied Energy 113:1349-62.

https://doi: 10.1016/j.apenergy.2013.08.091.

Yeh, H.-M. (2012), "Upward-type flat-plate solar air heaters attached with fins and operated by an internal recycling for improved performance." Review of. Journal of the Taiwan Institute of Chemical Engineers 43 (2):235-40.

https://doi: 10.1016/j.jtice.2011.10.008.

Yeh, H.-M., and Ho, C.-D. (2009), "Effect of external recycle on the performances of flat-plate solar air heaters with internal fins attached." Review of. Renewable Energy 34 (5):1340-7. https://doi: 10.1016/j.renene.2008.09.005. 